Article

\title{
Sustaining Rural Areas, Rural Tourism Enterprises and EU Development Policies: A Multi-Layer Conceptualisation of the Obstacles in Greece
}

\author{
Nikolaos Apostolopoulos 1,*, Panagiotis Liargovas ${ }^{2}$, Stavros Stavroyiannis ${ }^{3}$ (D), Ilias Makris ${ }^{3}$, \\ Sotiris Apostolopoulos ${ }^{3}$, Dimitrios Petropoulos ${ }^{4}$ and Eleni Anastasopoulou ${ }^{4}$ \\ 1 Department of Economics and Business, Neapolis University Pafos, Paphos 8042, Cyprus \\ 2 Department of Economics, University of the Peloponnese, 22100 Tripoli, Greece; liargova@uop.gr \\ 3 Department of Accounting and Finance, University of the Peloponnese, 24100 Kalamata, Greece; \\ computmath@gmail.com (S.S.); i.makris@teipel.gr (I.M.); sotirisapostolo@gmail.com (S.A.) \\ 4 School of Agriculture and Food, University of Peloponnese, 22100 Tripoli, Greece; \\ d.petro@us.uop.gr (D.P.); eeanasta@gmail.com (E.A.) \\ * Correspondence: n.apostolopoulos@nup.ac.cy; Tel.: +357-26-843300
}

Received: 18 August 2020; Accepted: 15 September 2020; Published: 17 September 2020

\begin{abstract}
The main lever for the development and promotion of rural tourism in Greece has been, and continues to be, through specific EU programmes. Rural tourism in Greece began with a long delay compared to other European countries. The development philosophy was (and still is) to increase rural incomes as a complement to agricultural and livestock production, not by degrading them. This theoretical paper presents previous research studies in rural tourism and EU development programmes and it describes how European financial tools intended for rural tourism were implemented in Greece. Furthermore, it describes the challenges faced by rural people involved in the development of rural tourism in seeking European funding through a multi-layer approach on the obstacles in the EU funds absorption capacity. The analysis shows that the legislation, design of the programmes, processes from local governments, bureaucracy and malpractices create constraints in the absorption of EU funds and the results in the rural tourism development are not the expected ones. It concludes that there is a need for reforms in the national institutional framework and structures along with a different philosophy in approaching the EU funding initiatives in rural areas.
\end{abstract}

Keywords: rural tourism; European funding; rural development; rural areas; Greece

\section{Introduction}

In Greece, rural tourism as an entrepreneurial activity began its growth with a delay of at least twenty years compared to other European countries and considered as a supplement to the rural income of rural residents [1]. Rural tourism began to develop in the late 1980s; until then the tourism product was promoted both by the state and by international tourist offices, mainly in coastal areas and islands. The population of rural settlements that migrated in the 1950s and 1960s to the major urban centres of Greece together with those who emigrated abroad maintained their ties with their homelands and at every opportunity took their short or long holidays in their villages [2]. They also maintained their crops that they had acquired from their parents, such as olive groves from which agricultural products were procured and boosted their total income. This is a major reason for the delay in the development of rural tourism in Greece. In the international literature, there is a wide range of studies on rural tourism in Greece: on the intentions of visitors to rural tourism units [3], on the attitudes of visitors to the rural tourism units [4], an examination of how the internet is used by rural tourism enterprises [5], on the influence of trademarks on rural tourism enterprises [6], on the impact of rural tourism on 
local development [7] and how the tourism-agriculture combination can support rural households [8]. There are also studies on female rural tourism in Greece [9-14], the role of rural tourism in local development $[1,15,16]$ and the quality norms of services and experience provided by rural tourism enterprises in relation to visitor satisfaction [17]. However, most of the research concerning the case of Greece deal with the emblematic LEADER Initiative and the amount contributed to local development via European financial tools that support and promote rural tourism enterprises [14,18-23].

The above discussion is part of a wider picture as there are rural areas facing a new challenging environment [24] and there are contradicting views regarding the rural development model that it has to frame the development programmes [25] since rural areas are multi-impacted and multi-influenced [26] by the policy approaches and mix followed [27]. To this extent, we argue that the research interest in EU development programmes implemented in the past or present for rural tourism enterprises in Greece is still at the starting point and a multilayered illustration of the obstacles in the EU funds absorption capacity of rural tourism enterprises can contribute to academic debate. This review paper aims to expand our current knowledge by presenting the academic discussion and examining the evolution of the European development tools used for rural tourism in Greece-how they were used and their contribution and the obstacles and side effects created during their approach and their development. Moreover, it aims to offer insights in policy implementation and it can be a useful navigator for policy makers. Finally, by understanding the obstacles, for instance, in LEADER initiatives as this paper unfolds, the debate on participation in EU development programmes [28] can be enriched.

Following this introductory section, the second section presents the academic discussion and debate around rural tourism and EU development programmes. The third section develops an overview of the EU programmes implemented in Greece. The fourth section unfolds the obstacles and reality of the implementation accompanied by evidence from relevant research studies. Finally, the last section sets the concluding remarks and policy suggestions.

\section{Literature Review: Rural Tourism and Challenges in the EU Development Initiatives}

The EU rural development programmes to support sustainable rural tourism and activities have a positive impact on rural economies [29-31]. It widely recognized that programmes such as LEADER are flagship initiatives for the EU sustainable rural-local development and sustainable rural tourism [32] as entrepreneurial ideas and efforts in rural tourism are recourseless and financial support such as EU rural development programmes can contribute in enhancing entrepreneurial activities in the rural tourism sphere [33]. To this extent, the EU development programmes offered the opportunity for the expansion of rural tourism [34] and the income of rural habitants increased as agriculture production started to decline [29]. The EU is suffering from agricultural land abandonment [35] and sustaining rural areas through alternatives ways is vital for the EU rural areas and the EU agricultural production. As a consequence, rural tourism became popular as an alternative form of tourism activity in less-favoured areas [36] and introduced economic activity beyond agriculture [37]; the EU through these development programmes and funding initiatives aimed to reverse the economic consequences in its territory of the land abandonment and the reduction of agricultural production in some countries. Indeed, according to Saxena et al. [38], the development of rural areas is moving outside the traditional concept of farming and integrated rural tourism has a significant role in the multi-functionality of rural areas. In fact, EU financial instruments can support small rural villages and remote areas to maintain and advance their traditional aspects linked with the rural landscape, cultural heritage and history [39].

However, it has to be recognized that the impact of rural tourism initiatives varies depending on the special characteristics of the area [40] and the EU development programmes are depending on the customization emphasis by the rural areas targeted [41]. As demonstrated by reference [42], through the lens of a critic, there is a distance between the impact presented and the practical impact in real rural life. Studies reveal that rural areas with vigorous characteristics benefit more in comparison with less-favoured and disadvantaged areas [43] and the disparities between rural areas widen [44]. In light of this, the effectiveness of these funding initiatives and programmes still remains controversial 
and it depends to some extent on the evaluation and impact assessment approach [30]. Assessing the impact of rural tourism is complicated due to lack of data and information [43] and, as a consequence, the impact of the financial support is not always clear.

With that said, the implementation and impact of the EU rural development programmes depend on external and unforeseen factors which set up a complicated situation. As rural areas are part of the wider economic environment, rural tourism is impacted by the economic climate and economic crises according to reference [45] and rural tourism businesses stopped operating due to the crisis [46]; as a consequence, the impact of EU development programmes varies depending on the overall economic climate. Furthermore, recent studies in EU development programmes reveal that the size of rural tourism businesses as beneficiaries influences the impact of EU funding [47]. Thus, examining economic and business variables linked with rural areas can maximize the potential of EU programmes targeting rural tourism and design an effective policy mix [48].

Another aspect linked with EU funding initiatives and rural tourism is the role of local governance and local stakeholders as the implementation of these programmes demands engagement of rural actors. Regional governments do not always facilitate the EU development programmes in rural tourism and their regional procedures create difficulties in implementation [49]. Indeed, local policy makers responsible for planning actions for EU development programmes have their own agendas which might be questioned from some groups of interest [50]. With that said, EU development in tourism is subject to criticism between planning and real actions [42] and the local actors play an important role in actually delivering successful initiatives of high impact for the rural areas and rural tourism. On top of that, local policy makers and regional authorities in some cases of EU states attempt to interfere in local partnerships running the development programmes [51]. Indeed, entrepreneurial activities in rural areas cannot easily be benefited by the EU programmes due to administrative barriers [52], highlighting the crucial role of the regional or even national model of governance in EU financing of rural areas. Even so, the desired multifunctionality of rural areas is interrelated with the governance and policy in the EU [53] and rural tourism, as a core part of the multifunctionality, is impacted negatively or positively depending on the policy processes and procedures. Thus, it cannot be neglected that the practices followed in EU funding initiatives even among rural areas in the same region might have different impacts in their sustainable development with the more developed areas to be more benefited [54]. Indeed, the institutional capacity affects the promotion of sustainable tourism in rural areas through EU programmes [32] and the local dynamics shape the actual outcome.

\section{European Financing Sources}

Support of rural tourism, and, therefore, rural entrepreneurship and economy, has always been channelled through specific European funding. The major programmes for financing rural tourism and agricultural income support were based on:

- The Integrated Mediterranean Programmes (EU Regulation 2088/85)

- The "Agro-tourism-Agrocraft" programme of Regulation 1257/99 on "Improving the efficiency of agricultural structures"

- The Regional Operational Programmes of Community Support Frameworks (CSFs)

- The Community LEADER Initiative (LEADER I, LEADER II, LEADER Plus and LEADER-RDP)

- The Integrated Rural Development Programmes (IRDPs)

Their aim is for the rural population to go beyond their usual role and to be further involved in the service sector, thus, increasing their income [14] without the degradation of agricultural and agro-livestock production [55]. At the same time, residents of urban centres should be given the opportunity to return to the countryside and escape the daily hustle and bustle of the city [14]. In this way, the agricultural production base is diversified, and the income of the rural population is not exclusively derived from the primary economy sector [13]. The rural population remains in the region; sustainable and multifunctional rural areas are created; rural tourism is connected with 
local agricultural products, as well as with gastronomic and cultural traditions; new jobs are created; new opportunities and perspectives are given to rural human resources and, overall, sustainable economic growth is generated. Today, the Greek countryside, with its familiarity with European programmes and funding, especially in rural tourism, has the potential in the current 2014-2020 programming period to tackle its challenges in more effective conditions for stainable development [56]. This has been made possible through the accumulated experience of human resources shaped by previous technological interventions and the action of the 54 Local Action Groups (LAGs) operating in 47 regional departments of the country. Moreover, the development of rural tourism must foremost be based on the principles of sustainable tourism, placing importance on preserving natural resources, avoiding environmental impact, achieving balanced rural growth, developing new forms of employment, promoting environmentally friendly behaviours and ensuring the active participation of the rural population while paying respect to the rural area [57].

\subsection{Mediterranean Integrated Programmes (Regulation 2088/85)}

The first attempt to support the rural world to ensure additional income from European funded rural tourism began with the stabilising of Mediterranean Integrated Programmes (MIPs). This is the application of Regulation 2085/85 [58]. It is the instigation of initiatives in the form of "hospitality" and the establishment of rural tourism cooperatives. These initiatives, and all which followed, were aimed at enhancing rural income by creating small sustainable enterprises from the rural world, complementing existing employment, creating new forms of employment, retaining the rural population in the countryside and strengthening the local market. Furthermore, they encouraged the creation of alternative tourism products and the cooperation of primary, secondary and tertiary sectors, as well as local and regional development through the infrastructure needed to support the rural tourism product and not only agriculture $[36,59,60]$. It should be noted that the share of the cost to a private farmer was $30 \%$, while the community contribution could not exceed $70 \%$ of the total cost.

A positive outcome of this first attempt was the establishment and operation of women's agricultural cooperatives that helped rural areas to evolve locally. A negative point was the absence of integrated development planning and the lack of boundaries for rural tourism destinations.

Subsequently, rural tourism investments were widened by Regulation 797/85, [61] entitled "To improve the effectiveness of agricultural structures". In essence, it was the first regulation defining the type of subsidised investments. Regulations 2328/91 [62] and 950/97 [63] followed in the framework of EU structural policy. Particularly, under the Regulation 950/97, aid was granted for rural tourism and agrocraft investments to farmers in mountainous and disadvantaged areas, with a view to supplementing their income from agriculture. This was based on Law 2520/97 (Government Gazette 173/1-9-1997) subsidising the interest rate of loans for the purchase of agricultural land near the place of permanent residence and at such a distance as to enable daily access aimed at the creation of sustainable exploitation, such as agrotourism-agrocraft activities, proprietary or leased farms, machinery, livestock, fixed investment and other non-agricultural income. Beneficiaries were young farmers and permanent residents of rural areas.

Despite the opportunities provided by the regulations for the period 1986-1998, the rural world indicated small to minimal interest in rural tourism investment and only $9 \%$ of the funds were absorbed. The businesses which were created related exclusively to rural tourism accommodations, with 820 rural tourism accommodations subsidised and 7600 beds created.

\subsection{Programme "Agrotourism-Agrocraft" of Regulation 1257/99 on "Improving the Efficiency of Agricultural Structures"}

Regulation 1257/99 [64] was the fifth regulation in approximately 15 years to indicate the interest of the EU and member states, and of farmer investors, in local growth in mountainous and disadvantaged rural areas. It has to be clarified the Regulation 1257/99 falls within Pillar I of EU Rural Development and refers to farmers whereas Pillar II funding opportunities do not refer to farmers but rural dwellers. 
This regulation, relating to the period 2000-2006, established a framework of principles of support for sustainable rural development and the Ministry of Agriculture was the responsible authority for its implementation. The regulation, like the previous ones, aimed at improving the rural world's income and maintaining the population of mountainous and disadvantaged areas, was of particular interest to new/young farmers. It focused on four key objectives: the multifunctionality of agriculture, a multi-sectoral approach to the rural economy, flexible rural development aid and transparency by focusing on mountainous and disadvantaged areas. The programme included the areas defined in Article 3 of Directive 75/268/EEC and financed investments involving tourist accommodation, catering and leisure centres, agri-livestock, craft activities, etc. The main categories of intervention were based on enhancing the agricultural sector and improving the competitiveness of agricultural products and rural areas, as well as maintaining the environment and enhancing the cultural element. For investments on agricultural holdings, the total aid could not exceed $40 \%$ of the investment or $50 \%$ for disadvantaged areas. These rates were increased to $60 \%$ for new/young farmers.

\subsection{Regional Operational Programmes (ROP) of the Community Support Frameworks (CSFs)}

Another source of European financing for rural tourism and craft activities was the Regional Operational Programmes (ROPs) of the Community Support Frameworks (CSFs). The first CSF was implemented in the period 1998-1994, the second in 1994-2000, the third in 2000-2006 and the fourth in 2006-2013. Responsibility, in the sense of the "competent body", was borne by the general secretariats of the 13 regions of the country, with the majority of these responsibilities falling on the elected regions. Farmers were entitled to join the ROPs, provided that at least a quarter of their income came from agriculture, agricultural cooperatives, producer groups, development links, municipalities and communities or companies with legal personality [65]. Subsidised activities were rural tourism, agrocraft, exhibition areas, cultural centres and more. The actions through the ROPs emphasised basic infrastructure, the exploitation of human resources and the protection of the environment. The fourth programming period had five ROPs. The ROP of Macedonia-Thrace, the ROP of Western Greece-Peloponnese-the Ionian Islands, the ROP of Crete and the Aegean Islands, the ROP of Thessaly-Central Greece-Epirus, and the ROP of Attica. The targeting of the National Strategic Reference Framework (NSRF) at the level of spatial priorities also concerned the development of the countryside, promoting the mild tourist action of mountain areas in parallel with the promotion of craft activities, agriculture and livestock. Emphasis was placed on the small-scale entrepreneurship of the rural world and especially young farmers.

\subsection{The Community Initiative LEADER (LEADER I, LEADER II, LEADER Plus and LEADER-RDP)}

The LEADER method was structured on eight features that illustrated the specificity of the programme and differentiated it from other programmes [66,67]. It started with (1) its spatial dimension, which was not subject to administrative boundaries but was based on the common identity of a region. Other major characteristics were (2) a bottom-up approach with the involvement of the targeted persons and bodies in its design, decisions and implementation; (3) management by Local Action Groups (LAGs); (4) innovation through specific proposals for mountainous and disadvantaged rural areas; (5) multi-sectoral integration, combining actions from different economic sectors; (6) networking through collective action; (7) transnational cooperation and (8) decentralised management and funding.

The programme started with LEADER I in the period 1991-1993; continued with LEADER II in 1994-1999, LEADER Plus in 2000-2006 and LEADER-RDP 2007-2013 and will continue with the Local Communities Initiative (CLLD), based on the LEADER approach, from 2014 to 2020.

\section{- Community Initiative LEADER I}

Aiming to support the countryside and transitions to rural development, in 1991, the EU launched the Community Initiative LEADER I with funding of $€ 1.155$ billion, out of which $€ 442$ million was 
from the EU, $€ 347$ million from member states and $€ 366$ million from local economic operators [68]. In the three years of the programme, from 1991 to 1993, approximately 17,000 beneficiaries and 22,000 enterprises were supported, while 8470 interventions were implemented in the agricultural sector, of which $42.15 \%$ concerned rural tourism hotel infrastructure [69]. For Greece, the total financial plan of LEADER I was $€ 161.8$ million, with rural tourism allocated around $€ 82.6$ million and a total of 1732 projects implemented. Outside of Greece, the rural tourism sector enjoyed $€ 807$ million in funding, of which only 84 projects $(10.41 \%)$ were implemented by farmers [68]. The programme was implemented in $217 \mathrm{EU}$ areas, of which 25 were Greek rural locations with populations of between 5000 and 100,000 .

\section{- Community Initiative LEADER II}

LEADER II was developed between 1994 and 1999 with a philosophy for developing mountainous and other disadvantaged areas, and retention of their populations. In contrast to LEADER I, LEADER II balanced the relationship between rural activity and parallel actions that created an opportunity for employment in the rural world through innovation and transferability of actions. LEADER II included measures such as capacity building, rural innovation programmes, transnational cooperation and networking [66]. The total budget of the programme reached $€ 8.33$ billion and created or sustained 100,000 jobs. In Greece, the budget amounted to 64 billion drachmas, of which community participation reached 51.7 billion drachmas and national participation 12.3 billion drachmas [66]. Some 1150 rural and alternative tourism development actions were implemented, of which $59 \%$ involved rural tourism accommodation, $18 \%$ alternative tourism, $10 \%$ in the catering sector, and $3.2 \%$ the promotion of tourism [70].

Positive results of LEADER I and II included the activity of local bodies in the development of mountainous and disadvantaged rural areas through integrated solutions that added non-agricultural income, the two-way transfer of experience of residents and operators of these regions through networks and the use of new technologies that modernised the production process and led areas out of isolation $[59,71]$. The disadvantages were the long delay in the start of the programme and the selection of beneficiaries, the adoption in many cases of unrealistic objectives and the dispersion of resources $[59,71]$.

\section{- Community Initiative LEADER Plus}

LEADER Plus was developed in the period 2000-2006 with two general objectives: to integrate sustainable development with high standards of countryside management and to alleviate rural isolation [72]. The difference between LEADER Plus and the previous LEADER programmes was the inclusion of other eligible areas throughout the countryside; although at a practical level this opening was limited, by choice, to a particular number of areas in order to ensure that European funding was substantial and avoided the overdispersion of resources. Beneficiaries were the Local Action Groups (LAGs). LEADER Plus was structured on four priority axes: the integrated pilot character of rural development strategies; the support for cooperation between rural and transnational areas; the networking of the rural areas; and the programme monitoring and evaluation management [73]. LEADER Plus funding at the European level totalled $€ 5.04$ billion, while the total budget for its initial phase for Greece was scheduled to be $€ 392.6$ million. However, the financing was $€ 368.7$ million and the amount of public expenditure amounted to approximately $€ 255.78$ million, of which $€ 186.13$ million was the community contribution [72,74]. Assessing the implementation and results of LEADER Plus requires addressing and resolving problems witnessed by LEADER I and II, in particular on information and access issues. Furthermore, consideration should be given to the positive impact of networking and partnerships, as well as the resonance and wider implementation received by the program., and to the negatives which included bureaucratic and administrative jams, as well as delays in financing [75]. 
- LEADER-Rural Development Programme (RDP) 2007-2013:

The National Rural Development Plan was supported by Regulation 1698/2005 that set Greece's priorities for 2007-2013. It was funded by the European Agricultural Fund for Rural Development with a view to improving competitiveness, environment and countryside; increasing quality of life in rural areas and differentiating the rural economy. The programme was approved by EU Decision 6012/29-11-2007. Among its strategic objectives were the building of local employment skills and diversification in rural areas through the LEADER approach, as well as the improvement in quality of life and encouragement of differentiation in the rural economy. LEADER-RDP 2007-2013 subsidised activities in 1174 villages in 26 different prefectures of Greece. Subsidies reached 50\%. Small tourist accommodation facilities and hotels up to 40 beds, camping facilities, visiting farms, restaurants, refreshment bars, traditional cafés and craft product production units were amongst the developments funded. Beneficiaries of the programme were private farmers, businesses operating or setting up non-profit organisations, local government organisations (LGOs) and LGO companies. At the same time, networking processes between regions and stakeholders were strengthened, support for innovative interventions was pursued and Local Action Groups' (LAGs') actions aimed at acquiring skills and stimulating the rural area were supported [76].

\subsection{Integrated Rural Development Programmes (IRDPs)}

Integrated interventions in mountainous and disadvantaged rural areas were also implemented through Integrated Rural Development Programmes (IRDPs) in 40 regions of Greece in 2000. Integrated into the third CSF, combining the reinforcement of investors through the realisation of social infrastructures, they aimed at removing the isolation of mountainous and disadvantaged rural areas as well as reducing intra-regional inequalities by creating sustainable conditions for specific populations, and highlighting and promoting the comparative advantages of these areas. The philosophy of IRDPs was based on the EU Regulation 1257/99.

Specific criteria were set for the inclusion of the regions in the Integrated Rural Development Programmes. These included the mountainousness of the areas; the decrease in population and employment in relation to the average of the region; the importance in the local economic activity of the primary sector which had a declining course; the possibility of gradual development of new forms of economic activity, such as agritourism and the home-based industry; the distance from the local centres of economic activity in combination with the absence of technical infrastructure and the limited diffusion of the development benefits that came from structural interventions of the last decade.

The criteria for the inclusion of the regions in the Integrated Rural Development Programmes were put in consultation with the regions and other bodies (e.g., chambers) and the final integration of the regions was in many cases a result of compromise and balance within the margins left by the generality of the inclusion criteria. For example, in the prefecture of Arcadia, the areas of the southern part of the prefecture of Arcadia and the then municipality of Tropaea Gortynia joined the Integrated Rural Development Programmes. After consultation in the above two areas, the municipality of Valtetsi, which is located just outside Tripoli and has nothing to do with the specifics of the other areas, joined. The above example was not an isolated case. This is one of the main reasons for the lack of uniformity in integration. The main reason, however, is the relief of mainland Greece in relation to the many distinct peculiarities of the regions as well as the special characteristics of island Greece. This creates an obstacle to the overall comparative representation. Any research approaches that have been made so far concern individual comparisons or comparisons between a few cases as each rural area has special characteristics.

The forty selected intervention areas included projects such as the establishment of farm management services, land improvements, basic services for the rural economy and population, the renovation and development of villages for the protection and preservation of the rural heritage, the management of agricultural water resources and the development and improvement of infrastructure related to agricultural development. Additionally included were the diversification of 
agricultural activities and activities related to agriculture to provide the possibility of creating multiple activities or obtaining alternative incomes. Finally, the encouragement of tourism and handicrafts; the protection of the environment in combination with agriculture, forestry, landscape conservation and the improvement of animal living conditions; investments to improve the competitiveness of primary processing; marketing enterprises; agricultural products, investments to improve and streamline logging and processing and marketing of forestry products were included.

The overall progress of the Axis 7 of Integrated Rural Development Programmes (2000-2006) at the end of the programmes period shows that only $60 \%$ of the total budget had signed legal commitments to start implementing the projects [77].

IRDPs continued during 2007-2013 based on the third axis of the Rural Development Programme "Alexandros Baltatzis", which included the measures of encouraging tourism activities, renovating and developing small villages, maintaining and upgrading rural heritage, supporting the creation and development of very small businesses, basic services for the economy and rural population and diversifying to non-agricultural activities. In particular, the measure of encouraging tourism activities included the reinforcement of investment projects aimed at improving and promoting the tourism product, enhancing employment, promoting the comparative advantages of these areas and increasing traffic. Among others, it provided for the establishment, expansion and modernisation of overnight accommodation, dining, recreation areas, etc. Beneficiaries were the local authorities and their businesses, as well as residents. For overnight facilities, the maximum rate was set at $60 \%$ and the maximum amount set at $€ 600,000$ for up to 40 beds.

\subsection{The 2014-2020 Programme Period: Local Communities Initiative (CLLD), Based on the LEADER Approach}

With a view to effectively addressing economic, social, environmental and demographic problems, Greece, in its official proposal to the EU for the Rural Development Programme 2014-2020, proposed the implementation of the Local Development Programme, with local community initiatives based on the principles and philosophy of LEADER [56]. This is essentially a method of integrating local development strategies for lagging rural areas, based on the active involvement of local economic and social stakeholders as well as civil society. CLLD is essentially a tool through which local communities can move forward with economically sustainable development, tackle local problems, strengthen the social cohesion of rural areas, innovate and generally create development in the direction of the "Horizon 2000" strategy. The LEADER action for 2014-2020 provided 19 measures, 19 to apply to mountainous and disadvantaged areas of municipal districts of fewer than 5000 inhabitants, with the exception of the islands. In addition to the 45 LEADER areas, Integrated Development Intervention Areas (IDIAs) are also defined for integrated interventions with a top-down approach [56]. In this context, the individual guidelines concern the interconnection of sectors and economic operators as well as the interconnection of the countryside with the urban area; the support of local entrepreneurship; the promotion of local identity; the implementation of the social actions to achieve social cohesion and combat poverty; the promotion of participation, cooperation, networking and the exchange of know-how between different regions, partners and states; the strengthening of youth and female entrepreneurship; the reinforcement of territorial innovation and competitiveness poles; the establishment of short supply chains; the amplification of local climate plans and management plans for Natura 2000 areas.

For the transition of the Greek rural economy into a strong and sustainable agri-food model that will include rural tourism, community resources of $€ 4.7$ billion were budgeted for the new programme period. From this fund, the implementation of private investment by small and medium-sized enterprises in rural tourism, cottage industry, crafts and services in rural areas is being allocated approximately $€ 400$ million. This amount should also be summed up together with parallel actions which indirectly affect the rural tourism product, such as aid to non-agricultural activities, with $€ 11,000$ to $€ 20,000$ for each beneficiary concerned; aid to the first establishment of young people in business in 
rural areas, with $€ 22,000$ to $€ 40,000$ for each beneficiary; or aid for 6500 new enterprises inside and outside the agricultural sector, with the aim of enhancing youth and women's entrepreneurship, etc.

The 2014-2020 program has not yet been completed. It is in progress and we do not have a final assessment of it. However, as in the previous operational programme periods, there are also delays in the implementation and absorption during the current period 2014-2020 and the previous experience has shown that only in the last months some progress significant progress is presented. With that said, these last months of the usual "last-minute" progress will not lead to the expected results due to the unforeseen COVID-19 crisis and the lockdown. On top of that, the structural reforms have not moved forward and the institutional framework remains the same. As a consequence, with a rapid assessment of the situation, by taking into account the absorption and implementation progress so far, the COVID-19 crisis and the lack of reforms, the outcome and impact of the 2014-2020 funding period might not be the expected one.

\section{Obstacles in the Absorption Capacity and Implementation}

The rural tourism product, and the economic development of the rural and disadvantaged areas, as well as the economic empowerment of the rural people living in those areas, create a need for understanding and shaping a new culture of dialogue and synthesis. This new culture must involve raising a plan and design collectively away from populism, localism, embodied solutions and special favours and include the support of target groups. Initially, three elements prevent rural tourism activities: lack of information, unstable conditions and the fear of failure strengthened by inexperience and doubt. These inhibitors can be overcome through specific actions of an organised state that will provide information, stabilize conditions, enhance the sense of security and certainty, encourage and strengthen finances, and provide expertise without intermediaries and special favours. Indeed, initiatives such LEADER did not always have the expected results due to the problematic relationship between the various levels of governance which hammered endogenous rural development [78] and this is why processes and structures matter $[79,80]$. To this end, and in order to overcome the obstacles to the EU supports, the actions that contribute to the acquisition of know-how, to the support and encouragement of the beneficiaries of local programmes, to the provision of improved access to information and data and the encouragement of the consistent implementation of the local strategy in line with developments in local conditions need to be initiated [56]. Indeed, the new rural paradigm considers rural development a multi-level and multi-actor scene [26]. Indeed, there is an intensive interaction of bottom-up, top-down and general external parameter streams $[27,81]$. To this extent, as is illustrated in Figure 1 and developed below, there is a multi-layer set of obstacles related to the absorption capacity of rural tourism enterprises: (1) obstacles from rurality and rural characteristics, (2) obstacles for the programme design, (3) obstacles from institutional structures, (4) obstacles from the institutional framework and (5) obstacles from the wider economic environment and climate. As it is depicted, the possibility of raising the obstacles as we move from the lower layer to the higher becomes limited as in higher levels the situation can be unforeseen and uncontrolled. Furthermore, this conceptualization shows that the upper layers have a strong impact on lower layers. For example, if setting up a business is not easy and the institutional framework is not friendly, then the absorption capacity comes through obstacles. The same issue exists for the layer of EU programmes design as the eligibility criteria can create obstacles in the absorption capacity. Thus, these layers are interrelated. 


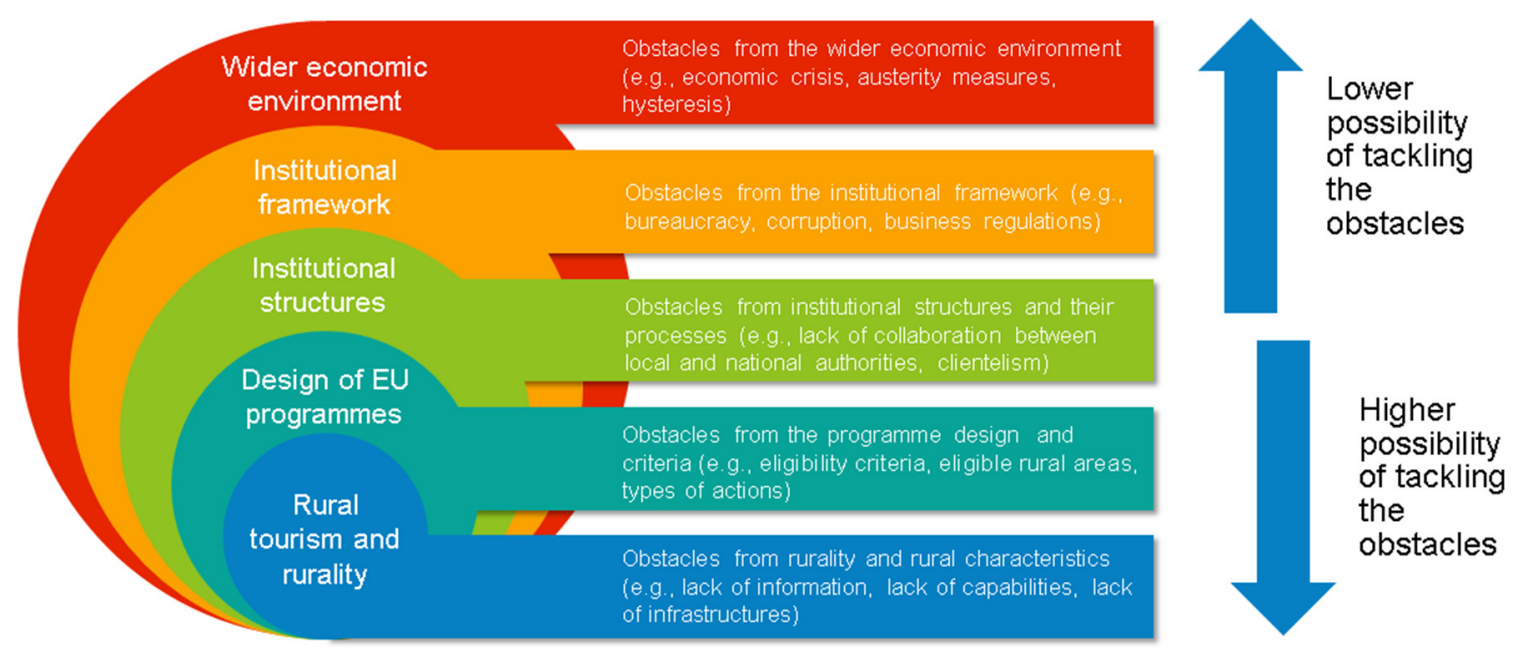

Figure 1. Multi-layered obstacles in EU funds absorption capacity and possibility of tackling the obstacles (Source: Authors' creation).

The research results in Greek rural tourism entrepreneurs vary depending on if they have benefited or not and at the same time the size of the tourism enterprise and its capacity influences the attitude on local governance and processes [31]. The EU funds stream as a form of grants for rural tourism entrepreneurs is not facilitated by legislation, institutional capacity and corruption [82]. Indeed, rural social entrepreneurs in tourism activities are struggling to get EU funding due to the legislation and bureaucracy in the regional authorities [83]. Indeed, in many cases, Local Action Groups lost their legitimacy due to non-transparent processes and by serving the interests of only specific groups [84]. Especially, small-medium enterprises consider the system complicated, and along with their lack of information by the regional authorities, they do not submit applications for inclusion in EU funding initiatives [85]. Indeed, the legislation and institutional framework create constraints in the absorbing capacity for the EU funds from Greek enterprises [86]. In light of this, entrepreneurs in rural areas might seek other forms of financing their enterprises such as loans and the rural enterprises should be supported with a variety of motives as "the beneficiaries (sic) enterprises in villages and in small towns are smaller and less than those in Serres, we conclude that enterprises in small villages and towns should have more motives to develop" [87] (p. 21). It seems that enterprises prefer in this case low or no-interest loans despite the strict regulations that these initiatives might have applied [87]. In addition, entrepreneurship in the Greek periphery is affected by the legislation's flaws regarding the eligibility criteria of participation based on the special characteristics even between areas of the same region [88]. Moreover, as it is revealed by empirical research conducted in tourism clusters in rural areas with memberships from rural tourism enterprises, entrepreneurs state that there is a need for more support from local governments [89]. As it is presented above, entrepreneurs view on their absorbing capacity, due to the legislation and institutional framework, is hindered by the obstacles and difficulties that they have to overcome in order for their enterprises to successfully and effectively benefit. However, barriers in implementation processes of LEADER can be limited when there a cooperation with "extra-regional" organisations [90] and collaborative actions can strengthen institutional capacity and facilitate entrepreneurial activity [91]. Indeed, a survey conducted of 174 rural tourism accommodation units in Greece reveals that collaboration on the one side and enhancing skills on the other can have a positive impact [92].

Management of the rural tourism product continues to be the subject of controversy [25]. There are those who claim that it must be developed on a case-by-case basis without intervening and following central planning. Others argue that rural tourism develops in a sensitive natural environment which must be protected due to the fact that entrepreneurial farmers are inexperienced and create small family-owned businesses that, without central care, are often unsustainable. It should be noted that of the approximately 675,000 rural households in Greece, 165,000 live in mountainous areas and 156,000 in 
island regions with severe problems of constricting livestock farming. Added to this, the performance of the agricultural sector is in the lowest seats of the EU-15 countries [93]. It is clear that without state intervention to provide financial support to the social fabric, these rural areas will suffer suffocating conditions to economic activities with a huge negative impact on the national economy.

In Greece, the development of the rural tourism product was mainly driven by local development initiatives without comprehensive planning of local development. Moreover, such policies have been practically impossible, since Greece has been deprived in many cases of both General Urban Plans (GSPs) and Local Planning and Spatial Plans (SCHOAP). The absence of GIS and CSDP prevent investment in local and regional development opportunities. In any case, their absence does not contribute to sustainable development or the development of serious strategic development plans. Lastly, the prevailing situation does not impede unauthorised arbitrary construction, does not systematically promote the drastic restriction of off-site construction and degrades the environmental impact.

Rural tourism must be linked to the principles of the European Charter for Sustainable Tourism, which in some cases in Greece has not been taken into account. This should not be repeated in the programme period 2021-2027. In order to follow the principles of sustainable tourism, it must consider the environmental impacts of the planning, management and monitoring of rural tourism actions. It should implement the sustainability and protection systems of sensitive areas; preserve cultural heritage; balance managing natural resources; use environmentally friendly means of transport; support the local economy; ensure the active participation of the local community; give employment opportunities to the local population and especially young farmers, women and people with disabilities; promote environmentally friendly behaviours; support the natural and cultural environment and improve the quality of life $[57,65]$. If rural tourism is incompatible with the principles of sustainability then there is a risk of environmental degradation and excessive development at the expense of agricultural production and at the expense of altering cultural characteristics.

In a tough, competitive environment, and even in times of economic crisis, the offered rural tourism services play a decisive role in the financial survival of rural tourism companies as they are a determining factor in the choice of rural accommodation [94]. Indeed, the economic crisis in Greece set a scene of rural attractiveness in terms of counterurbanisation and rural areas might be benefited if they have policy support $[95,96]$. However, rural tourism units often face problems due to lack of experience, knowledge and skills [97]. The programme period 2014-2020 focuses on upgrading rural tourism services by promoting the cooperation of small businesses. It aims at upgrading the services offered, specialisation, acquiring know-how, organising common working methods, promoting rural tourism product access and improving access to information, knowledge, and capital markets to raise funds. With that said, previous experience on LEADER programmes should be capitalized on and there is an opportunity for it to be a learning process with benefits for rural society [98]. The collaboration of small and scattered rural tourism businesses will help them to become financially viable, better organise the marketing of their services, share facilities and resources, gain access to capital markets, provide direct and reliable information, create sustainable and more functional rural areas and showcase their regional comparative advantages.

The progress and evolution of rural tourism businesses, which are financed and supported by European funds, are linked to the harmonisation of European directives with the national law of Greece. In recent years, Greece has shown significant positive results on harmonisation of European directives with national law, based on the official results of the Single Market Scoreboard [99]. It is an indicator that leads us to conclude that the problems of the past, where non-timely harmonisation of European directives deterred smooth implementation of European programmes, are now eliminated. Especially on environmental issues, Greece will face few problems in this regard in the programme period 2021-2027. However, where problems will be significant is in the issue of administering justice. Thousands of cases are pending in Greek courts creating a stumbling block in the development process and in the rural economy, where in many cases there are blockages in changing property titles and the reclassification of areas $[100,101]$. Thousands of such cases end up in the courtroom, seeking justice. 
In 2015, there were over 28,000 cases pending before the Council of State; more than 60,000 cases in the nine administrative appeals courts; more than 370,000 cases in the 30 Administrative Courts; some 30,000 cases in the Court of Auditors and nearly 2700 in the Supreme Court. According to the World Bank in 2019, the resolution of a legal dispute between companies in Greece took 1711 days on average [102]. No one knows how many cases are pending in the forestry dispute resolution committees, where the rural world is mainly involved. The substandard situation of justice has such a negative effect on the citizens' sense of law that if major justice reforms are not carried out, they will have a significant negative impact on the implementation of the programmes for the 2014-2020 period. Too often the citizen of Greece is in the midst of ineffective and bureaucratic public administration and the impression that Greece lacks a sense of law. The problem of pluralism must be added to the problems of justice in Greece. More than 4000 laws have been passed in the last thirty years and over 110,000 ministerial decisions have been issued [103]. Particularly in forestry laws, the high complexity creates opaque procedures and corruption. This is important as practice has shown that legal disputes in rural areas related to land-use or between the rural residents block investments in rural tourism funded by EU development programmes.

The above analysis and conceptualization of the obstacles related to the absorption capacity of a multi-layered nature show the complexity of creating successful development programmes, as many factors are interrelated. It is argued that the obstacles at the lower layers have a higher possibility of tackling them as interventions in increasing information flows in rural areas or enhancing skills can be controlled and with minimal effort to be done. The same issue exists with the design of the EU development programmes and their criteria. However, obstacles in upper layers, strongly affecting rural areas, can be long-term problems or depend on the overall economic climate and as a consequence cannot be easily tackled.

\section{Conclusions-Policy Suggestions}

The EU has established several models of rural development, rural income enhancement, quality of life improvement, local and regional development and environmental protection. In this context, rural tourism aims at reducing regional disparities, encouraging tourism and craft activities, reintegratiing rural and disadvantaged areas into the production system, preventing isolation and withering, complementing agricultural income, keeping the rural population in the countryside and improving age composition by stimulating job places for young people. It has also aimed to improve the social status of the female farmer and promote the socio-economic role they play in rural areas. Furthermore, it made it possible to link tourism with agricultural livestock and craft products, and more generally to link local production with culinary and cultural traditions. All the aforementioned in many cases increased employment, created new jobs, improved the standard of living, maintained the ecological balance, contributed to environmental protection, balanced management of natural resources and made it possible for visitors to become acquainted with nature and cultural heritage. Finally, meeting the need for short breaks many times during the year, preserving local architecture and culture and enhancing communication and forming harmonious relationships between the rural world and the tourism product were also positive outcomes. The EU, through the specific financing of rural tourism programmes, has upgraded the rural and disadvantaged areas of Greece and boosted their economies by creating new activities [104]. There have been positive and negative elements in this process. The negative elements will be reported in order not to repeat the programme period 2014-2020 that is completed and the programme period 2021-2027 that is now being planned, but in any case, the balance is positive. Tourism investments in the rural world are an important tool for rural entrepreneurship, preservation of rural activities, and contribution to the emerging European rural model. [105]. Rural tourism has responded to the deterioration and contraction of agricultural and livestock production, to the phenomenon of economic imbalance, to the rapid increase of the tourist product, and particularly at the increasing turn of people to nature to enjoy their few days off, often several times in the same year. The role of the agricultural entrepreneur in the rural tourism sector 
is complex and multi-layered. Beyond their pure rural and livestock activity comes a businessman or businesswoman providing services, involving himself or herself in sponsored tour services, and links the agricultural and craft production with the rural tourism product. It essentially links the primary, secondary, and tertiary local production sectors.

Today, in Greece, there is an adequate level of rural tourism offered, albeit with the need to better manage the terms and conditions of the resources available of the programme period 2014-2020 and the programme period 2021-2027 planned. An acquaintance with European resources and experience in programme management were gained. Experienced and skilled human resources can respond to new challenges and also seize the ability to intervene. In addition, the technological equipment provided to LAGs and local development companies, provided by previous community funds, contributes to a better use of the 2014-2020 resources.

It should be continually perceived and projected that the rural programmes, such as LEADER, are not for the development of tourism, but aim at an overall rural development, with the rural people who are permanent residents of these areas at their centre. Consequently, rural tourism helps to boost extra-agricultural income by linking agricultural activity to tourism. That alone cannot address the problems of the rural world in mountainous and disadvantaged areas, but it can balance rural development by emphasising the quality of the rural tourism product. It is not a self-contained and independent activity, but a complementary operation without it being an opportunistic activity.

The programme period 2014-2020, with its financial interventions, created hopes for a recovery of the Greek economy and a frame for investment interest. At the same time, there are weaknesses that the economic crisis itself has created and Greece has to solve them for the economy to recover, escape recession, absorb all of the European resources on offer and generate the investment interest. Greece has formed a negative prevailing atmosphere for the creation of public or private projects, and this is exacerbated by the impossibility of obtaining bank loans, letters of guarantee, etc. These problems are magnified in the rural population, who may not want to get involved in rural tourism, due to inexperience and lack of information. Strong political reform interventions are needed to resolve these weaknesses.

The current economic conditions in Greece are made to remove the dangers of commercialisation and mass tourism of rural tourism, a phenomenon that is often encountered in foreign countries where the characteristics of the mountainous landscape and traditional culture have been altered. The local ecosystems have been destroyed. Furthermore, maybe because of the current decline of economic activity in Greece, nowadays, there is an imminent risk of impact on socio-economic development with the mass construction of holiday homes in the rural areas as we experienced in the past in Western societies [106], but we believe that at some point the causes and the effects of the crisis will be overcome by Greece. To avoid negative phenomena in the new programme period, Greece must formulate comprehensive planning of interventions financed by European funds that will protect the mountainous and remote areas from mass tourism and commercialisation. According to Baud-Bovy [107], tourism planning must be integrated "into socio-economic policies, the natural and anthropogenic environment, socio-cultural traditions, the various relevant sectors of the economy and economic plans", and not with the pretext of the economic crisis to leave Greece open to mass-marketing and commercialisation conditions incompatible with sustainable development.

The interconnection of rural tourism in Greece with networks of similar products in other European countries is considered essential for the 2014-2020 programme period. There are several rural tourism networks in Europe, with a distinctive case being the European Centre for Ecological and Agricultural Tourism (ECEAT). It has been in operation since 1992, focusing on eco-rural tourism, with particular emphasis on the development of sustainable small-scale tourism in rural areas and in organic farming. A corresponding network in Greece is the "Association of Unions of Rural tourism Greece" (AUAG) that networks dispersed tourism unions and businesses to improve the quality of rural tourism. AUAG has developed special relationships with the European Federation of Rural Tourism EuroGites (www.eurogites.org) and is also a member of the Board of Directors of the European 
Rural Tourism Federation. In the new programme period, the further networking of Greek rural tourism associations will create substantial partnerships in rural tourism. Online information on rural tourism will be promoted through information and communication technologies and product creation (branding) and wider cooperation in rural tourism will be achieved. The demand for certification of rural tourism and rural tourism businesses will be strengthened, with self-assessment and certification processes advanced. The quality standards process, such as HACCP and ISO, will be applied to rural tourism businesses. The recently developed Greek Law 3089/18 for quality assessment and labelling in agrotourism provides a framework in order for quality assurance in the sector to be increased and it an important step towards setting up specific rules and processes. However, the results of this law, the impact of its application and how it is embedded in the rural philosophy will be revealed the coming years. Finally, the conditions for Greek rural tourism businesses to access the European and international markets will be improved. These initiatives need to be reinforced with specific policies on the part of Greece, and not just at the economic level.

In most cases, the agricultural interventions require the involvement of regional and local authorities and their services are facing almost the same problems as public administration in Greece. In practical terms, this means that it is difficult for the existing administration, without deep reforms, to meet the requirements of the new programme period 2021-2027. There is a risk of the same situation that Greece experienced in the past, where bureaucratic inefficiency, political and self-governing interventions, partisanship and special favours dominated the state. This kept the nation away from meritocratic processes, technological upgrading and forming friendly and reliable relations with its citizens. A new value system in the public sector must be created, providing reliable services for social justice, improved productivity and a friendly environment for citizens [108]. With that said, we cannot emphasize only on the economic growth produced by rural tourism enterprises in general, as its contribution is important in enhancing income for rural residents and it is even more important in terms of sustaining the social characteristics of rural areas. Thus, the EU development programmes should not be considered in practice as financing rural businesses but as an opportunity to revitalizing rural areas.

Finally, in terms of research, this paper points to some future research avenues: (1) there is a need to investigate the EU funding initiatives in rural tourism by comparing the implementation between different rural areas by taking into account the rural characteristics of each area; (2) more intensive research is needed in revealing rural entrepreneurs' points of view on the obstacles that they are facing and their absorption capacity by triangulating the data with local policy makers' points of view and (3) as the COVID-19 crisis created new challenges for the rural areas and especially for rural tourism, there is a need for the impact of EU funding in rural tourism on rural tourism enterprises to be investigated through the lens of this new situation, including determining if EU funding helped them to demonstrate resilience or not.

Author Contributions: Conceptualization, S.S. and S.A.; formal analysis, N.A., P.L., S.S. and S.A.; investigation, P.A., D.P. and E.A.; resources, P.L., I.M., D.P. and E.A.; supervision, N.A.; writing-original draft, N.A., I.M. and E.A. All authors have read and agreed to the published version of the manuscript.

Funding: This research was funded by the University of Peloponnese.

Conflicts of Interest: The authors declare no conflict of interest.

\section{References}

1. Karagianni, M.; Georgakopoulou, S.; Delitheou, V. Agrotourism: A lever for rural development based on the cultural reserve of Greece. In Smart Tourism as a Driver for Culture and Sustainability; Springer: Berlin/Heidelberg, Germany, 2018; pp. 193-206.

2. Iakovidou, O.; Koutsouris, A.; Partalidou, M. The development of Rural Tourism in Greece, through the initiative LEADER II: The case of Northern and Central Chalkidiki. New Mediterr. Mediterr. J. Econ. Agric. Environ. 2002, 1, 32-38. 
3. Hasanagas, N.; Pousini, M.; Goula, M. Exploring Determinants and Relations Between Nature-Based ("ECO”) Tourism and Agro-tourism. Reg. Sci. Inq. 2018, 10, 171-185.

4. Christou, E.; Chatzigeorgiou, C.; Simeli, I. Destination Branding and Visitor Loyalty: The Case of Agritourism; University Library of Munich: Munich, Germany, 2018; pp. 237-245.

5. Andreopoulou, Z.; Lemonakis, C.; Koliouska, C.; Zopounidis, C. Internet and agrotourism sector for regional development in Crete: A multicriteria ranking. Int. J. Inf. Decis. Sci. 2017, 9, 116-127.

6. Chatzigeorgiou, C.; Christou, E.; Simeli, I. Confidence and loyalty for agrotourism brands: The Lesvos paradigm. Tour. Int. Multidiscip. J. Tour. 2019, 14, 151-166.

7. Karampela, S.; Kizos, T.; Spilanis, I. Evaluating the impact of agritourism on local development in small islands. Isl. Stud. J. 2016, 11, 161-176.

8. Koutsouris, A.; Gidarakou, I.; Grava, F.; Michailidis, A. The phantom of (agri) tourism and agriculture symbiosis? A Greek case study. Tour. Manag. Perspect. 2014, 12, 94-103. [CrossRef]

9. Chatzitheodoridis, F.; Kontogeorgos, A.; Liltsi, P.; Apostolidou, I.; Michailidis, A.; Loizou, E. Small Women's Cooperatives in less favoured and mountainous areas under economic instability. Agric. Econ. Rev. 2016, 17, 63-79.

10. Lassithiotaki, A. Rural women and entrepreneurship: A case study in Heraklion Crete Prefecture, Greece. J. Dev. Entrep. 2011, 16, 269-284. [CrossRef]

11. Anthopoulou, T. Rural women in local agrofood production: Between entrepreneurial initiatives and family strategies. A case study in Greece. J. Rural Stud. 2010, 26, 394-403. [CrossRef]

12. Koutsou, S.; Iakovidou, O.; Gotsinas, N. Women's co-operatives in Greece: An ongoing story of battles, successes and problems. J. Rural Coop. 2003, 31, 47-57.

13. Kazakopoulos, L.; Gidarakou, I. Young women farm heads in Greek agriculture: Entering farming through policy incentives. J. Rural Stud. 2003, 19, 397-410. [CrossRef]

14. Iakovidou, O. Women's Agrotourist Cooperatives in Greece: Key Elementsfor Their Successful Operation. J. Rural Coop. 2002, 30, 13-24.

15. Karampela, S.; Kizos, T. Agritourism and local development: Evidence from two case studies in Greece. Int. J. Tour. Res. 2018, 20, 566-577. [CrossRef]

16. Kizos, T.; Iosifides, T. The contradictions of agrotourism development in Greece: Evidence from three case studies. S. Eur. Soc. Politics 2007, 12, 59-77. [CrossRef]

17. Chatzigeorgiou, C.; Simeli, I. Perception of service quality in agrotourism accommodations: Impact on guest loyalty and re-visit intentions. J. Tour. Herit. Serv. Mark. 2017, 3, 33-41.

18. Caraveli, H. The LEADER Programme as a vehicle in promoting social capital in rural regions: A critical assessment and examples from the case of Greece. Rural Areas Dev. 2017, 14, 169-184.

19. Papadopoulou, E.; Hasanagas, N.; Harvey, D. Analysis of rural development policy networks in Greece; Is LEADER really different? Land Use Policy 2011, 28, 663-673. [CrossRef]

20. Loizou, E.; Chatzitheodoridis, F.; Michailidis, A.; Kontogeorgos, A.; Mattas, K. Leader approach performance assessment in a Greek rural region. In Proceedings of the Poster Paper Presented at the EAAE 2014 Congress "Agri-Food and Rural Innovations for Healthier Societies", Ljubljana, Slovenia, 26-29 August 2014.

21. Vlontzos, G.; Arabatzis, G.; Manos, B. Investigation of the relative efficiency of LEADER+ in rural areas of Northern Greece. Int. J. Green Econ. 9 2014, 8, 37-48. [CrossRef]

22. Karafolas, S. Public financial support to investments in rural areas: The case of the region of Thessaly in Greece. Int. J. Econ. Sci. Appl. Res. 2013, 6, 81-101.

23. Arabatzis, G.; Aggelopoulos, S.; Tsiantikoudis, S. Rural development and LEADER plus in Greece: Evaluation of local action groups. J. Food Agric. 2010, 8, 302-307.

24. Phillipson, J.; Gorton, M.; Turner, R.; Shucksmith, M.; Aitken-McDermott, K.; Areal, F.; Cowie, P.; Hubbard, C.; Maioli, S.; McAreavey, R.; et al. The COVID-19 Pandemic and Its Implications for Rural Economies. Sustainability 2020, 12, 3973. [CrossRef]

25. Galdeano-Gómez, E.; Aznar-Sánchez, J.A.; Pérez-Mesa, J.C. The complexity of theories on rural development in Europe: An analysis of the paradigmatic case of Almería (South-east Spain). Sociol. Rural. 2011, 51, 54-78. [CrossRef]

26. Van der Ploeg, J.D.; Renting, H.; Brunori, G.; Knickel, K.; Mannion, J.; Marsden, T.; De Roest, K.; Guzmán, E.; Ventura, F. Rural development: From practices and policies towards theory. Sociol. Rural. 2000, 40, 391-408. [CrossRef] 
27. Bosworth, G.; Annibal, I.; Carroll, T.; Price, L.; Sellick, J.; Shepherd, J. Empowering Local Action through Neo-Endogenous Development; The Case of LEADER in England. Sociol. Rural. 2016, 56, 427-449. [CrossRef]

28. Müller, O.; Sutter, O.; Wohlgemuth, S. Learning to LEADER. Ritualised Performances of 'Participation'in Local Arenas of Participatory Rural Governance. Sociol. Rural. 2020, 60, 222-242.

29. Panyik, E.; Costa, C.; Rátz, T. Implementing integrated rural tourism: An event-based approach. Tour. Manag. 2011, 32, 1352-1363. [CrossRef]

30. Tirado Ballesteros, J.G.; Hernández Hernández, M. Assessing the impact of EU rural development programs on tourism. Tour. Plan. Dev. 2017, 14, 149-166. [CrossRef]

31. Fotiadis, A.; Nuryyev, G.; Achyldurdyyeva, J.; Spyridou, A. The impact of EU sponsorship, size, and geographic characteristics on rural tourism development. Sustainability 2019, 11, 2375. [CrossRef]

32. McAreavey, R.; McDonagh, J. Sustainable rural tourism: Lessons for rural development. Sociol. Rural. 2011, 51, 175-194. [CrossRef]

33. Sgroi, F.; Donia, E.; Mineo, A.M. Agritourism and local development: A methodology for assessing the role of public contributions in the creation of competitive advantage. Land Use Policy 2018, 77, 676-682. [CrossRef]

34. Castellano-Álvarez, F.J.; del Río-Rama, M.D.L.C.; Álvarez-García, J.; Durán-Sánchez, A. Limitations of Rural Tourism as an Economic Diversification and Regional Development Instrument. The Case Study of the Region of La Vera. Sustainability 2019, 11, 3309. [CrossRef]

35. Renwick, A.; Jansson, T.; Verburg, P.H.; Revoredo-Giha, C.; Britz, W.; Gocht, A.; McCracken, D. Policy reform and agricultural land abandonment in the EU. Land Use Policy 2013, 30, 446-457. [CrossRef]

36. Anthopoulou, T.; Iakovidou, O.; Koutsouris, A.; Spilianis, I. Spatial and Developmental dimensions of agrotourism in Greece. In Reconstruction of the Rural Area; Apostolopoulos, K., Ed.; Stamouli Publications: Athens, Greece, 2000; pp. 485-501.

37. Van Huylenbroeck, G.; Durand, G. Multifunctional Agriculture: A New Paradigm for European Agriculture and Rural Development; Ashgate Publishing: Farnham, UK, 2003.

38. Saxena, G.; Clark, G.; Oliver, T.; Ilbery, B. Conceptualizing integrated rural tourism. Tour. Geogr. 2007, 9, 347-370. [CrossRef]

39. Manta, O. Financial instruments for tourism and agrotourism in Romania. In Caring and Sharing: The Cultural Heritage Environment as an Agent for Change; Springer: Cham, Switzerland, 2019; pp. 345-359.

40. Slee, B. Rural Tourism and Recreation in the EU. Rural Policies Employ. Trans. Exp. 2019, 333-350. [CrossRef]

41. Apostolopoulos, N.; Ratten, V.; Stavroyiannis, S.; Makris, I.; Apostolopoulos, S.; Liargovas, P. Rural health enterprises in the EU context: A systematic literature review and research agenda. J. Enterprising Communities 2020, 14, 563-582. [CrossRef]

42. Ribeiro, M.; Marques, C. Rural tourism and the development of less favoured areas-between rhetoric and practice. Int. J. Tour. Res. 2002, 4, 211-220. [CrossRef]

43. González-Ramiro, A.; Gonçalves, G.; Sánchez-Ríos, A.; Jeong, J.S. Using a VGI and GIS-based multicriteria approach for assessing the potential of rural tourism in Extremadura (Spain). Sustainability 2016, 8, 1144. [CrossRef]

44. Masot, A.N.; Alonso, G.C. 25 Years of the leader initiative as European Rural Development Policy: The case of Extremadura (SW Spain). Eur. Country. 2017, 9, 302-316. [CrossRef]

45. Chatzitheodoridis, F.; Kontogeorgos, A.; Loizou, E. The lean years: Private investment in the Greek rural areas. Proced. Econ. Financ. 2014, 14, 137-146. [CrossRef]

46. Chatzitheodoridis, F.; Kontogeorgos, A. Exploring of a Small-Scale Tourism Product under Economic Instability: The Case of a Greek Rural Border Area. Economies 2020, 8, 52. [CrossRef]

47. Giaccio, V.; Mastronardi, L.; Marino, D.; Giannelli, A.; Scardera, A. Do rural policies impact on tourism development in Italy? A Case study of agritourism. Sustainability 2018, 10, 2938. [CrossRef]

48. Giaccio, V.; Giannelli, A.; Mastronardi, L. Explaining determinants of agri-tourism income: Evidence from Italy. Tour. Rev. 2018. [CrossRef]

49. Tirado Ballesteros, J.G.; Hernández, M.H. Promoting tourism through the EU LEADER programme: Understanding Local Action Group governance. Eur. Plan. Stud. 2019, 27, 396-414. [CrossRef]

50. Panyik, E. Rural tourism governance: Determinants of policy-makers' support for tourism development. Tour. Plan. Dev. 2015, 12, 48-72. [CrossRef] 
51. Furmankiewicz, M.; Knieć, W.; Atterton, J. Rural governance in the new EU member states: The experience of the Polish LEADER+ Pilot Programme (2004-2008). In Governance in Transition; Springer: Dordrecht, The Netherlands, 2015; pp. 133-153.

52. Dan, M.C.; Popescu, C. Entrepreneurship in the rural areas of Romania. The impact of the 2007-2013 EU funding programmes. In Proceedings of the International Conference on Business Excellence; Sciendo: Warszawa, Poland, 2017; Volume 11, pp. 1129-1136.

53. Brouwer, F. (Ed.) Sustaining Agriculture and the Rural Environment: Governance, Policy, and Multifunctionality; Edward Elgar Publishing: Cheltenham, UK, 2004.

54. Nieto Masot, A.; Cárdenas Alonso, G. The rural development policy in Extremadura (SW Spain): Spatial location analysis of leader projects. Isprs Int. J. Geo-Inf. 2018, 7, 76. [CrossRef]

55. Sfakianakis, K. Alternative Forms of Tourism; Ellin Publications, ION Publishing Group: Athens, Greece, 2000.

56. EAFRD. Rural Development, Rural Development Program 2014-2020; official submission; EAFRD: Formentera, Spain, 2014.

57. Lagos, D.; Diakomichalis, M. Agrotourism and Sustainable Local Development: The Case of Greece. In Agrotourism-Ecotourism and Organic Sheep and Goat Farming: Innovation, Science and Production; Ellin Publications: Athens, Greece, 2011.

58. Official Journal of the European Communities. Council Regulation (EEC) No 2088/85 of. 23 July 1985 on Integrated Mediterranean Programs, L 197; EU: Athens, Greece, 1985.

59. Apostolopoulos, K.; Sdrali, D. Alternative and Mild Urban Tourism; Greek Publishing: Athens, Greece, 2009.

60. Kaldis, P.; Alexopoulos, G.; Theodoropoulou, E.; Giannouzakou, A. Agrotourism and Development; Pedagogical Institute: Athens, Greece, 2000.

61. Council Regulation. Council Regulation (EEC) no 797/85 of 12 March 1985 on Improving the Efficiency of Agricultural Structures, O.J.L-093/30.03.85: 1-18; Council Regulation: Luxembourg, 1985.

62. Council Regulation. Council Regulation (EEC) no 2328/91 of 15 July 1991 on Improving the Efficiency of Agricultural Structures, O.J.L-06.08.1991: 1-21; Council Regulation: Luxembourg, 1991.

63. Council Regulation. Council Regulation (EC) no 950/97 of 20 May 1997 on Improving the Efficiency of Agricultural Structures, L 142/1; Council Regulation: Brussels, Belgium, 1997.

64. Council Regulation. Council Regulation (EC) no 1257/99 of 17 May 1999 on Support the Rural Development through the European Agricultural Guidance and Guarantee Fund (EAGGF) and for Amending and Repealing Certain Regulations, EE160/26-6-1999 (CNS/1998/102); Council Regulation: Luxembourg, 1999.

65. Andriotis, K. Sustainability and Alternative Tourism; Stamoulis Publications: Athens, Greece, 2008.

66. European Commission. Ex-post Evaluation of the Community Initiative LEADER II.; Final Report; European Commission: Vienna, Australia, 2003.

67. Emmanouilidou, M. LEADER: 'The Initiative for the Development of Rural Tourism in the Greek Countryside'; Olga, I., Ed.; Mediterranean Tourism beyond the coast: New trends in tourism and social organization of the area; Thessaloniki, Greece, 2005; pp. 415-416. Available online: http://www.gbip.gr/book/127602/Collective_Work/Mediterranean_Tourism_Beyond_the_Coastline: _New_Trends_in_Tourism_and_the_Social_Organisation_of_Space (accessed on 17 September 2020).

68. Ministry of Agriculture. Final Report of the Community Initiative LEADER I, Issue 1; Ministry of Agriculture: Athens, Greece, 1996.

69. European Commission. Ex-Post Evaluation of the Leader I Community Initiative. General Report; European Commission: Brussels, Belgium, 1999.

70. Ministry of Agriculture. Operational Program of the Community Initiative LEADER+ (2000-2006), Volume B, in Advance Evaluation, Athens, Ministry of Agriculture; Ministry of Agriculture: Athens, Greece, 2002.

71. AEIDL. Assessing the Added Value of the LEADER Approach, Rural Innovation Dossier 4; LEADER European Observatory: Brussels, Belgium, 1999.

72. Ministry of Agriculture. Operational Program of the Community Initiative LEADER+ (2000-2006). Ministry of Agriculture: Athens, Greece, 2003.

73. Ministry of Agriculture. Operational Program of the Community Initiative Leader+ (2000-2006) Volume BIn Advance Evaluation of the National Leader+ Program, Directorate of Planning and Agricultural Structures; Ministry of Agriculture: Athens, Greece, 2000. 
74. Ministry of Rural Development and Food. Operational Program of the Community Initiative Leader+ (2000-2006), 9th Monitoring Committee Meeting, Heraklion, Crete, Management Service Ltd. LEADER+, 2006; Ministry of Rural Development and Food: Athens, Greece, 2006.

75. European Commission. "Rural Development in the Service of Employment and Economic Growth", DirectorateGeneral for Agriculture and Rural Development; European Commission: Luxembourg; Athens, Greece, 2006.

76. Ministry of Rural Development and Food. Rural Development Program of Greece 2007-2013, Publication of Special Secretariat for Programming and Applications 3rd CSF; Ministry of Rural Development and Food: Athens, Greece, 2008.

77. Chatzitheodoridis, F.; Michailidis, A.; Tsilochristos, D.; Kazaki, S. Integrated Rural Development Programmes in Greece: An Empirical Approach to their Management, Practice and Results. Aeihoros 2006, 5, 58-90.

78. Barke, M.; Newton, M. The EU LEADER initiative and endogenous rural development: The application of the programme in two rural areas of Andalusia, southern Spain. J. Rural Stud. 1997, 13, 319-341. [CrossRef]

79. Ray, C. Territory, structures and interpretation-Two case studies of the European Union's LEADER I programme. J. Rural Stud. 1998, 14, 79-87. [CrossRef]

80. Furmankiewicz, M.; Macken-Walsh, Á. Government within governance? Polish rural development partnerships through the lens of functional representation. J. Rural Stud. 2016, 46, 12-22. [CrossRef]

81. Bosworth, G.; Price, L.; Hakulinen, V.; Marango, S. Rural Social Innovation and Neo-endogenous Rural Development. In Neoendogenous Development in European Rural Areas; Cejudo, E., Navarro, F., Eds.; Springer Geography: Cham, Switzerland, 2020.

82. Smith, A. Obstacles to the growth of alternative tourism in Greece. Afr. J. Hosp. Tour. Leis. 2011, 1, 1-8.

83. Apostolopoulos, N.; Newbery, R.; Gkartzios, M. Social enterprise and community resilience: Examining a Greek response to turbulent times. J. Rural Stud. 2019, 70, 215-224. [CrossRef]

84. Esparcia, J.; Escribano, J.; Serrano, J.J. From development to power relations and territorial governance: Increasing the leadership role of LEADER Local Action Groups in Spain. J. Rural Stud. 2015, 42, $29-42$. [CrossRef]

85. Liargovas, P.; Apostolopoulos, N.; Pappas, I.; Kakouris, A. SMEs and green growth: The effectiveness of support mechanisms and initiatives matters. In Green Economy in the Western Balkan; Emerald Publishing Limited: West Yorkshire, UK, 2017.

86. Huliaras, A.; Petropoulos, S. European money in Greece: In search of the real impact of EU structural funds. Jcms: J. Common Mark. Stud. 2016, 54, 1332-1349. [CrossRef]

87. Balomenou, C.; Maliari, M. Support of local entrepreneurship: An empirical investigation for Serres-Greece. Spatium 2013, 16-21. [CrossRef]

88. Balomenou, C.; Maliari, M. Support of Local Entrepreneurship During Periods of Crisis: A Case Study for Serres-Greece on NSRF Programmes. Proced. Econ. Financ. 2015, 33, 535-551.

89. Partalidou, M.; Koutsou, S. Locally and socially embedded tourism clusters in rural Greece. Tour. Int. Multidiscip. J. Tour. 2012, 7, 99-116.

90. Nordberg, K.; Mariussen, Å.; Virkkala, S. Community-driven social innovation and quadruple helix coordination in rural development. Case study on LEADER group Aktion Österbotten. J. Rural Stud. 2020, 79, 157-168. [CrossRef]

91. Scott, M. Building institutional capacity in rural Northern Ireland: The role of partnership governance in the LEADER II programme. J. Rural Stud. 2004, 20, 49-59. [CrossRef]

92. Fotiadis, A.; Yeh, S.S.; Huan, T.C.T. Applying configural analysis to explaining rural-tourism success recipes. J. Bus. Res. 2016, 69, 1479-1483. [CrossRef]

93. Eurostat. Performance of the Agricultural Sector. 2019. Available online: https://ec.europa.eu/eurostat/ statistics-explained/index.php/Performance_of_the_agricultural_sector\#Value_of_agricultural_output (accessed on 5 September 2020).

94. Potocnik, M. Multi-Attribute Model for the Assessment of Farm Tourism's Supply Quality. Unpublished. Master's Thesis, University of Maribor, Maribor, Slovenia, 2006.

95. Anthopoulou, T.; Kaberis, N.; Petrou, M. Aspects and experiences of crisis in rural Greece. Narratives of rural resilience. J. Rural Stud. 2017, 52, 1-11. [CrossRef]

96. Figueiredo, E.; Partalidou, M.; Koutsou, S. "It's a different kind of happy"-narratives on the 'back to the countryside'motivations and strategies in times of crisis: A comparison between Greece and Portugal. In Proceedings of the XII Congreso Iberoamericano de Estudios Rurales (CIER), Segovia, Spain, 4-6 July 2018. 
97. Sharpley, R. Rural Tourism and the Challenge of Tourism Diversification: The Case of Cyprus. Tour. Manag. 2002, 23, 233-244. [CrossRef]

98. High, C.; Nemes, G. Social learning in LEADER: Exogenous, endogenous and hybrid evaluation in rural development. Sociol. Rural. 2007, 47, 103-119. [CrossRef]

99. European Commission. Single Market Scoreboard, Transposition, 2015. Available online: http://ec.europa. eu/single-market-scpreboard (accessed on 17 September 2020).

100. Sarantis, D. The Challenge of Accelerating Greek Judicial Procedure. In International Conference on Electronic Government and the Information Systems Perspective; Springer: Cham, Switzerland, 2017; pp. 251-260.

101. Sitaropoulos, N. Delayed Justice in Greek Administrative Courts and Lack of an Effective Domestic Remedy-Comment on Interim Resolution CM/ResDh (2007) 74. Essex Hum. Rights Rev. 2011, 7, 16-31.

102. World Bank Group. Doing Business 2020, Economy Profile Greece, Comparing Business Regulation in 190 Economies; World Bank Group: Washington, DC, USA, 2020.

103. Argyros, A. The Fair Satisfaction due to the Fair Duration of the Trial; Sakkoula Publications: Athens, Greece, 2015.

104. Gousiou, A.; Spilanis, I.; Kizos, T. Is agrotourism "agro" or tourism: Evidence from agrotourist holdings in Lesvos, Greece. Anatol. Int. J. Tour. Hosp. Res. 2001, 12, 6-23.

105. Commission of the European Communities. Council Regulation (EC) No.1257/1999, L160/80; Commission of the European Communities: Luxemburg, 1999.

106. Hobson, W. A research report on private residence clubs: A new concept for second home ownership. Int. J. Hosp. Manag. 2002, 21, 285-300. [CrossRef]

107. Baud-Bovy, M. New concepts in planning for tourism and recreation. Tour. Manag. 1982, 3, $308-313$. [CrossRef]

108. Apostolopoulos, N.; Liargovas, P. Unlock local forces and improve legitimacy: A decision making scheme in the European Union towards environmental change. Eur. Policy Anal. 2018, 4, 146-165. [CrossRef]

(C) 2020 by the authors. Licensee MDPI, Basel, Switzerland. This article is an open access article distributed under the terms and conditions of the Creative Commons Attribution (CC BY) license (http://creativecommons.org/licenses/by/4.0/). 